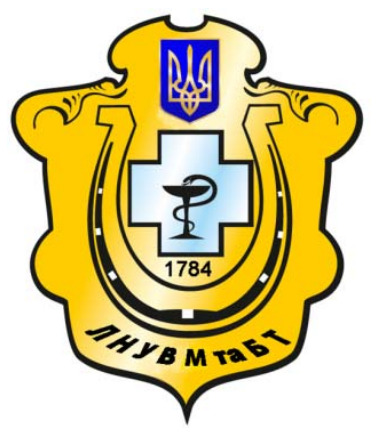

Науковий вісник Львівського національного університету ветеринарної медицини та біотехнологій імені С.3. Гжицького

Scientific Messenger of Lviv National University of Veterinary Medicine and Biotechnologies named after S.Z. Gzhytskyj

doi:10.15421/nvlvet7605

ISSN 2519-2701 print

ISSN 2518-1327 online

http://nvlvet.com.ua/

УДК 338.48:65.01 (01)

\title{
Стан підприсмництва у сфері сільського зеленого туризму в Україні та за кордоном
}

\author{
І.В. Власенко \\ vlasenkovanya@mail.ru
}

Вінницький торговельно-економічний інститут Киїського національного торговельно-економічного університету, вул. Соборна, 70, м. Вінниия, 21050 Украӥна

\begin{abstract}
У статті розглянуто питання розвитку сільського зеленого туризму на селі. Цей вид відпочинку має найдемократичнішу цінову політику. В результаті досліджень встановлено, щяо в Украӥні сільський зелений туризм перебуває на початковій стадії свого становлення і розвитку, а підприємництво у иій сфері все ще належить до ризикованих видів діяльності. Певну роль у функиіонуванні та розвитку сільського зеленого туризму відіграє Спілка сприяння розвитку сільського зеленого туризму в Україні. В статі показано, шчо за кордоном лідерами щзодо реалізації послуг сільського зеленого туризму є Франиія та Іспанія, де сільський туризм вже сформувався у високорентабельну та прибуткову галузь економіки та вийшов на рівень міжнародної економічної спеціалізації. В статті також розкривається, що ринок послуг зеленого туризму в Украӥні має низку недоліків, які доведеться вирімувати вже найближчим часом, якщо Украйна планує подальшу євроінтеграчію.
\end{abstract}

Ключові слова: село, сільський зелений туризм, иіна, якість, гостинність, відпочинок, агрооселя, ринок послуг.

\section{Состояние предпринимательства в сфере сельского зеленого туризма в Украине и за рубежом}

\author{
И.В. Власенко \\ vlasenkovanya@mail.ru \\ Винницкий торгово-экономический институт Киевского национального торгово-экономического \\ университета, ул. Соборная, 70, Винница, 21050, Украина
}

\begin{abstract}
В статье рассмотрены вопросы развития сельского зеленого туризма на селе. Этот вид отдыха имеет демократическую иеновую политику. В результате исследований установлено, что в Украине сельский зеленый туризм находится на начальной стадии своего становления и развития, а предпринимательство в этой сфере все еще относится к рискованным видам деятельности. Определенную роль в функиионировании и развитии сельского зеленого туризма играет Союз содействия развитию сельского зеленого туризма в Украине. В статье показано, что за рубежом лидерами по реализации услуг сельского зеленого туризма является Франция и Испания, где сельский туризм уже сформировался в высокорентабельную и прибыльную отрасль экономики и вышел на уровень международной экономической специализаиии. В статье также раскрывается, что рынок услуг зеленого туризма в Украине имеет ряд недостатков, которые предстоит решать в ближайшее время, если Украина планирует дальнейшую евроинтеграцию.
\end{abstract}

Ключевые слова: село, сельский зеленый туризм, цена, качество, гостеприимство, отдых, агроусадьба, рынок услуг.

Citation:

Vlasenko, I.V. (2017). State enterprise in rural green tourism Ukraine and abroad. Scientific Messenger LNUVMBT named after S.Z. Gzhytskyj, 19(76), 26-30. 


\title{
State enterprise in rural green tourism Ukraine and abroad
}

\author{
I.V. Vlasenko \\ vlasenkovanya@mail.ru \\ Vinnitsa Trade and Economic Institute of Kyiv National University of Trade and Economics, \\ Cathedral Str., 70, Vinnitsa, 21050, Ukraine
}

\begin{abstract}
The article discusses the development of green tourism in rural areas. This type of holiday is the most democratic pricing. Tourists are attracted convenient settlements, current private pensions, closeness to nature, the ratio of price / quality, hospitality and homely atmosphere with recreation. As a result of studies found that in Ukraine rural green tourism in the initial stages of its formation and development, and entrepreneurship in this area still belongs to risky activities. A role in the functioning and development of green tourism plays Union to promote rural green tourism in Ukraine. The article shows that the Union for Promotion of Rural Green Tourism in Ukraine approved the program of voluntary categorization in green tourism «Ukrainian hospitable mansion». The paper shows that the proposed sign "Ukrainian hospitable mansion» is assigned ahrooseli reports of potential consumers of services of appropriate quality housing and service levels and enables farmers to set fee. This sign is given by the Union to promote rural green tourism and can be used as a marketing tool. In the analyzed statistics on rural green tourism is noted that in the Volyn region, where the Shatsky Lakes, which is the main place of summer vacation, 2751 provided services to tourists, and nine ahroosel Cherkasy region visited only 289 tourists. In 2015, the undisputed leader in the provision of services of green tourism remains IvanoFrankivsk region, which visited - 16.903 tourists. In Bukovina village has 75 private estates, are engaged in eco-tourism. Their number has increased compared to the year 2015 mynulym - 26 units. However, in Ukraine in 2015 compared to 2013 the number of businesses in this area decreased by 52 ahrooseli, including by entities that are located in the annexed Crimea. In some areas, particularly Zaporozhye, Odessa, Kharkiv and Kherson, ahrooseli ceased operations (including - 6 estates), that these areas, according to official statistics, disappeared from the map of green tourism in Ukraine. In sex shows that foreign leaders to implement green tourism services are France and Spain, where rural tourism has emerged in highly profitable and lucrative sector of the economy and reached the level of international economic specialization. In sex also revealed that the market of services of green tourism in Ukraine has a number of shortcomings to be addressed in the near future if Ukraine plans to further European integration.
\end{abstract}

Key words: village, rural green tourism, the price, quality, hospitality, leisure, ahrooselya market services.

\section{Вступ}

Актуальність теми. Швидкий ритм життя, урбанізація, впровадження високих технологій та комунікацій створили умови для формування та розвитку сільського зеленого туризму. В Україні цей вид туризму набув поширення в останньому десятиріччі та переживає період становлення як окремої сфери підприємницької діяльності. Враховуючи особливості географічного положення, сприятливість кліматичних умов, культури і традицій, у нашій країні є достатні передумови для розвитку сільського зеленого туризму.

Аналіз останніх досліджень. Проблеми розвитку підприємництва в сфері сільського зеленого туризму та особливості його становлення в системі аграрної економіки є в полі зору багатьох вітчизняних і зарубіжних вчених. Варто відзначити праці вітчизняних науковців, які досліджують особливості розвитку економічної ситуації в Україні та світі і роль туристичної галузі, зокрема: О.О. Фарйон, О.Г. Топчієв, С.В. Дутчак, А.А. Жигірь, В.Г. Іванова, О.О. Корчинська та інші (Topchiiev, 2005; Ivanova, 2010; Dutchak, 2011; Zhyhir, 2012; Farion, 2013; Korchynska, 2015). Серед зарубіжних дослідників особливе місце посідають праці O. Faryon, S. Nordin, W.W. Gaworecki та інших (Gaworecki, 2003; Nordin, 2013; Faryon and Korchynskyy, 2013).

Незажаючи на значну кількість наукових праць, питання розвитку сільського зеленого туризму потребує подальшого вирішення.

Метою роботи було обгрунтувати можливості розвитку зеленого туризму на селі як фактору підви- щення соціально-економічного стану сільського населення.

\section{Результати та їх обговорення}

Викладення основного матеріалу. В результаті проведених досліджень встановлено, що в Україні сільський зелений туризм перебуває на початковій стадії свого становлення і розвитку, а підприємництво у цій сфері все ще належить до ризикованих видів діяльності. Певну роль у функціонуванні та розвитку сільського зеленого туризму відіграє Спілка сприяння розвитку сільського зеленого туризму в Україні. У квітні 2011 року виповнилось 15 років з дня заснування Спілки сприяння розвитку сільського зеленого туризму в Україні. За цей час багато було зроблено, але не все заплановане вдалося здійснити. Сільський зелений туризм нині стає все більш популярним у світі. В 2016 році понад 400 сільських господарів в Карпатському регіоні готові прийняти гостей у своїх садибах, а по Україні цей показник досягає значення близько 1000 садиб. Туристів приваблює зручна система поселення, сучасне обладнання приватних пансіонатів, близькість до природи, співвідношення ціна/якість, гостинність та домашня атмосфера при організації відпочинку. Цей вид відпочинку має найдемократичнішу цінову політику. Так, правлінням спілки сприяння розвитку сільського зеленого туризму в Україні затверджено програму Добровільної категоризації у сфері сільського зеленого туризму «Українська гостинна садиба». Зроблено це, як зазначено в Положенні, з метою розвитку форм поселень у сільських садибах, підвищення якості комплексного 
обслуговування туристів, надаваних послуг розміщення та сприяння розвитку сільських територій в Україні.

Добровільна категоризація у сфері сільського зеленого туризму «Українська гостинна садиба» має чотири категорії, які позначаються відповідним знаком (рис. 1).

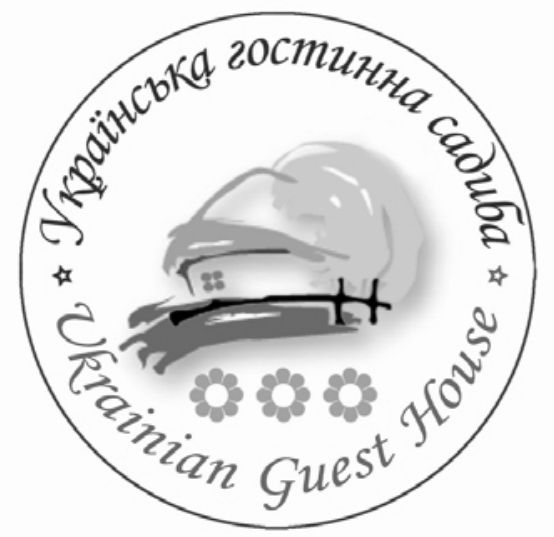

Рис. 1. Знак «Українська гостинна садиба»

Знак «Українська гостинна садиба» містить словосполучення двома мовами: українською - «Українська гостинна садиба» та англійською - «Ukrainian Guest House» та зображення української хатинки. Під хатинкою розміщені квітки мальви - від однієї до трьох (рис. 1). Кількість квіток визначає категорію агрооселі:

базова категорія - позначається без квітки;

перша - однією квіткою ;

друга - двома квітками \% ;

третя - трьома квітками के ซ

Такий знак повідомляє потенційних споживачів про відповідну якість житлових умов та рівень послуг, а також дає змогу сільському господарю встановити плату. Цей знак надається Спілкою сприяння розвитку сільського зеленого туризму та може використовуватися як інструмент маркетингу. Надається він на термін три роки, що підтверджується відповідним сертифікатом. Категоризація садиб є добровільною та здійснюється на підставі заяви власника агрооселі, до якої ще додаються відповідні документи.

Присвоєння певної категорії для суб'єктів підприємництва у сфері сільського зеленого туризму в Україні, на жаль, поки що не становить жодної інформаційної чи рекламної цінності. Це зумовлено тим, що така категоризація є добровільною, не закріпленою в законодавчому порядку нормою ведення підприємництва, як і сама підприємницька діяльність у сфері сільського зеленого туризму. Тобто, з одного боку, власники агроосель не зацікавлені в проведенні такої категоризації, а з іншого - «кількість квітів» на фасаді садиби не мотивує відвідувачів користуватися іiі послугами. Цінові пропозиції умовно можна поділити на п’ять категорій, залежно від таких умов:

- побутові - наявність ванни (душу), туалету в самому будинку, а також користування холодильником, газовою або електроплитою;

- інфраструктура - як далеко розташоване госпо- дарство від жвавих трас, річки, лісу, озера чи моря, наявність поряд медпункту, магазину;

- додаткові пропозиції - домашнє харчування, трансфер, екскурсії, походи в гори, вивчення мов, риболовля, катання на конях, домашні овочі та фрукти, молоко, мед;

- сезон - дорожче може коштувати відпочинок під час Новорічних, Різдвяних і Пасхальних свят, влітку, у популярному розвинутому регіоні, дешевше -- міжсезоння (весна і осінь);

- цінність регіону - наявність визначних пам'яток архітектури, цікавих ландшафтів, екологія.

Попри добровільну категоризацію садиб, в Україні Державна служба статистики проводить збір та аналіз інформації, у тому числі про підприємництво у сфері сільського зеленого туризму. Однак в Україні у 2015 р. порівняно з 2013 р. кількість суб'єктів підприємництва в цій сфері зменшилась на 52 агрооселі за рахунок суб'єктів господарювання, які розташовані на території анексованого Криму. Варто відзначити і те, що в окремих областях, зокрема Запорізькій, Одеській, Харківській та Херсонській, агрооселі припинили свою діяльність (разом - 6 садиб), тобто ці області, за даними офіційної статистики, зникли з карти сільського зеленого туризму в Україні.

Це знову підтверджує висновок про значний вплив чинника політичної нестабільності в цих регіонах, хоча аналогічна тенденція до зменшення офіційної кількості агроосель, але 3 меншою динамікою, спостерігається також в Івано-Франківській, Львівській, Закарпатській та Чернівецькій областях.

Аналізуючи статистичні дані щодо сільського зеленого туризму та кількості туристів, які скористались послугами агроосель у 2015 р., можна зробити висновок про те, що розміщення осередків і результати розвитку та функціонування цього виду підприємницької діяльності насамперед залежать від природних умов. Так, двома агрооселями Волинської області, де розташовані Шацькі озера, які є основним місцем літнього відпочинку, надано послуги 2751 туристові, а дев'ять агроосель Черкаської області відвідало лише 289 туристів.

Якщо ж оцінювати кількість туристів, які скористалися послугами сільського зеленого туризму у 2015 р. в розрізі областей України, то беззаперечним лідером залишається Івано-Франківська область (рис. 2).

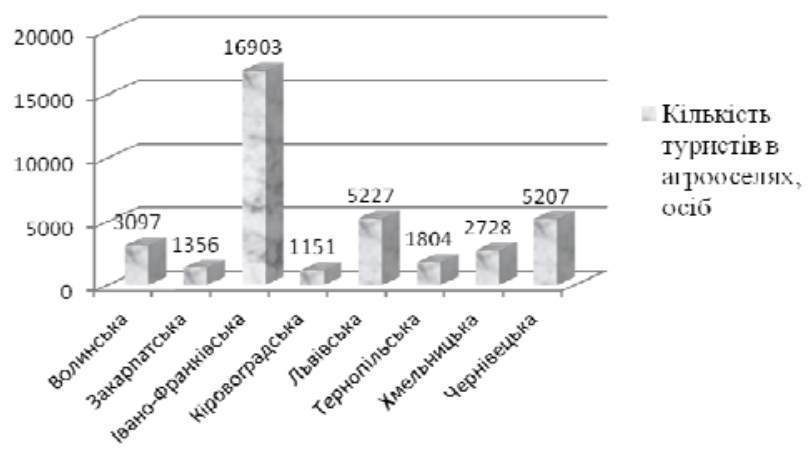

Рис. 2. Кількість осіб, які у 2015 р. скористалися послугами агроосель в областях України *

* За даними Державної служби статистики України 
У селах під впливом високого безробіття активізуються процеси пошуку зайнятості селян. Розвиток сільського зеленого туризму в умовах безробіття сільських жителів може певною мірою забезпечити робочі місця для них, підвищити рівень їх зайнятості. Це сприятиме розширенню сфери послуг, зокрема торгівлі, громадського харчування. Україна на сучасному етапі в наданні туристичних послуг поступається перед багатьма країнами, хоча в сільському господарстві, зеленому туризмі як щодо обсягів, так і потенційних можливостей, держава має значні перспективи. Тільки через непорозуміння та невідповідальне ставлення до справи керівних кадрів на регіональному рівні не повною мірою використовується природні потенційні можливості організації зеленого туризму і державою втрачаються великі гроші, які можна використати для подальшого розвитку сільського туризму і матеріального забезпечення мешканців сіл та відповідно збільшення надходжень до бюджету країни у вигляді податків. Потенційні можливості розвитку зеленого туризму практично у всіх регіонах України безмежні як щодо іноземних туристів, так і щодо вітчизняних.

За обсягами розвитку та реалізації послуг сільського зеленого туризму лідерами є Франція та Іспанія, де сільський туризм вже сформувався у високорентабельну та прибуткову галузь економіки та вийшов на рівень міжнародної економічної спеціалізації.

За останні роки у Франції зелений туризм набув широких масштабів. У 1971 р. в Франції була створена асоціація «Туризм в сільській місцевості», яка координує організацію сільського, зеленого туризму в національному масштабі всієї державі. Для сільського зеленого туризму Франції поширеним $є$ поняття «Gites ruraux», що об'єднує всі варіанти проживання: вілли, ферми, садиби чи апартаменти. Варто відзначити, що у Франції агротуристична садиба - це не обов'язково володіння фермерів. Фактично власником агротуристичної садиби виступає лише кожен третій фермер. Решта власників - це городяни і туристичні компанії.

Сільський зелений туризм по-іспанськи - це Turismo Rural. На сьогодні інфраструктура сільського туризму Іспанії налічує близько 10 тисяч установ. Серед них є маленькі і великі готелі - скромні та 3 усіма зручностями (наприклад, саунами і басейнами). Крім того, можна ознайомитися із сільськогосподарським виробництвом (вирощуванням фруктів і овочів, тваринництвом), майстерністю виноробства, виробленням сирів і ковбас, взяти участь у дегустаціях, відвідати майстер-класи тощо. Найпоширенішою формою сільського туризму в Іспанії є сільський го- тель «фінка» (finca). В Іспанії фінка - це, зазвичай, сільський будинок або ціла ферма, яка пропонує свої послуги туристам. Загалом Іспанія утримує пальму першості в розвитку сільського туризму серед країн Європи. У цій країні існує понад 5 тис. об'єктів для відпочинку в сільській місцевості із загальною кількістю ліжко-місць 27000. Існує категоризація 750 сільських готелів за системою «INNS OF SPAIN», яким присвоюються 1-4 тюльпани. Деякі готелі функціонують на базі монастирів, історичних замків. Незважаючи на те, що послуги сільського відпочинку в Італії майже вдвічі дорожчі, ніж в Іспанії чи Франції, ними щорічно користується близько 2 млн осіб (з них $78 \%$ - італійці). А щорічний прибуток від сільського туризму перевищує 350 млн доларів. Загалом розвиток сільського зеленого туризму в Італії має давні традиції та з року в рік продовжує нарощувати обсяги діяльності.

Сільський туризм у європейських країнах (особливо у Франції, Італії, Іспанії, Польщі) є невід'ємною складовою соціально-економічного розвитку села та обгрунтовує необхідність ефективного використання потенціалу сільських територій для зростання рівня зайнятості сільського населення та вдосконалення інфраструктури села.

Розвиток підприємництва у сфері сільського зеленого туризму на території України відбувається досить нерівномірно, що зумовлено природнокліматичними умовами, наявністю історикокультурних об'єктів та збереженням національних самобутніх традицій.

У нашій державі $є$ ентузіасти в кожному регіоні, які можуть організувати туристичні центри там, де їх немає. В окремих містах обласного підпорядкування, де $\epsilon$ потенційні можливості для зеленого туризму, необхідно створити відділи, які сприятимуть розвитку даного виду туризму та надаватимуть консультаційні послуги. Владою і громадськими організаціями Чернівецької області проведено цілу низку наукових конференцій, навчальних семінарів 3 надання практичної допомоги з питань розвитку сільського туризму.

В результаті проведеної роботи на Буковині діє 75 сільських приватних садиб, які займаються екологічним туризмом. Їхня чисельність збільшилась у 2016 році порівняно з минулим роком на 26 одиниць. Розвиток сільського зеленого туризму варто розцінювати як стратегічний пріоритет подальшого соціальноекономічного поступу Чернівецької області. Частина Карпатського регіону є цікавою для зовнішніх та внутрішніх туристів у зв'язку з сезонною різноманіттю розваг, зокрема літній та зимовий відпочинок дуже відрізняється (табл. 1).

Табличя 1

Різноманіття відпочинку в Карпатському регіоні

\begin{tabular}{|c|c|}
\hline \multicolumn{2}{|c|}{ Програма сільського «зеленого туризму та баз відпочинку» } \\
\hline Влітку & Взимку \\
\hline $\begin{array}{l}\text { пішохідні одноденні екскурсії в гори; } \\
\text { велотуризм та інші види активного відпочинку; } \\
\text { збирання ягід та грибів; } \\
\text { пішохідні багатоденні туристичні походи; } \\
\text { автобусні екскурсії }\end{array}$ & $\begin{array}{l}\text { катання на снігоходах; } \\
\text { катання на ковзанах; } \\
\text { пішохідні одноденні екскурсії в гори; } \\
\text { святкування Нового року та Різдва }\end{array}$ \\
\hline
\end{tabular}


Водночас ринок послуг зеленого туризму в Україні має низку недоліків, які доведеться вирішувати вже найближчим часом, якщо Україна планує подальшу євроінтеграцію (рис. 3).

\begin{tabular}{|c|}
\hline Недоліки зеленого туризму: \\
\hline нестача кваліфікованих кадрів \\
\hline прогалини в системі податкового \\
\hline $\begin{array}{l}\text { недостатня кількість спеціальних навчальних } \\
\text { закладів для підготовки спеціалістів }\end{array}$ \\
\hline низькосортність рекламних матеріалів \\
\hline
\end{tabular}

Рис. 3. Недоліки ринку послуг зеленого туризму в Україні

Для того, щоб сільський зелений туризм в Україні дійсно розвивався, необхідно звернути увагу на відсутність спрощеного обліку, звітності і оподаткування. Діюча податкова політика не завжди є послідовною в змінах форм оподаткування. Сдиний податок ставки 6 і 10 відсотків від усіх надходжень є найоптимальнішим варіантом як для малих підприємств, так і для податкових органів. Форма спрощеного оподаткування, тобто єдиний податок, за діючим законодавством обирається щорічно. Головною перевагою єдиного податку є простота його нарахування як для підприємств, так і для перевірки податковими органами.

\section{Висновки}

Сільський зелений туризм - явище багатогранне. Звичайно, цей вид підприємницької діяльності не вирішить усіх соціальних проблем на селі, але дасть можливість одержувати додаткові доходи при незначних вкладеннях коштів самих селян, а завдяки підтримці органів місцевого самоврядування і держави можлива поступова ліквідація негативних явищ як у сільському господарстві, так і в інших сферах госпо- дарської діяльності на селі. Це також один із чинників стратегії подолання бідності в сільській місцевості.

\section{Бібліографічні посилання}

Farion, O.O. (2013). Funktsionuvannia silskoho zelenoho turyzmu v Ukraini v umovakh rynkovoi ekonomiky. Innovatsiina ekonomika. 8(46), 183-185 (in Ukrainian).

Topchiiev, O.H. (2005). Suspilno-heohrafichni doslidzhennia: metodolohiia, metody, metodyky : navch. posib. Odesa: Astroprynt (in Ukrainian).

Dutchak, S.V. (2011). Upravlinnia rehionalnym rozvytkom turyzmu: navch. posib. dlia studentiv vyshchykh navch. Zakladiv. Chernivtsi: Cherniv. nats. un-t (in Ukrainian).

Zhyhir, A.A. (2012). Ekolohizatsiia pidpryiemnytstva v ahrarnii sferi. Ahrosvit. 5, 9-12 (in Ukrainian).

Ivanova, V.H. (2010). «Silskyi turyzm» yak katehoriia nauky administratyvnoho prava ta zakonodavstva Ukrainy. Pravo i suspilstvo. 3, 119-125 (in Ukrainian).

Korchynska, O.O. (2015). Ekonomichni osnovy rozvytku silskykh terytorii. Efektyvnist funktsionuvannia silskohospodarskykh pidpryiemstv. Problematyka 2015 r.: innovatsiinyi rozvytok pidpryiemstv ahrarnoi sfery ekonomiky : materialy IV Mizhnar. nauk.-prakt. Internet-konf. Lviv: LNAU, 105-107 (in Ukrainian).

Faryon, O., Korchynskyy, O. (2013). Legislative and regulatory aspects of the regulation of rural green tourism in Ukraine. Development scenarios and alternatives in the modern economy. San Francisco: B\&M Publishing, 154-157.

Nordin, S. (2013). Tourism Clustering \& Innovation Paths to Economic Growth \& Development. ETOUR: European Tourism Research Institute, 90.

Gaworecki, W.W. (2003). Turystyka. Waszawa: Pol. wydaw. Ekonomiczne.

Стаття надійшла до редакиії 15.03.2017 